\title{
Pensononowoor
}

2021, vol. 85, 3-18

https://doi.org/10.12657/denbio.085.002

\author{
Zhen Zhang*, Guoqing Jin, Zhongping Feng, Linshan Sun, \\ Zhichun Zhou*
}

\section{Provenance-specific climate sensitivity of Pinus massoniana - a multi-environmental trial in subtropical China}

Received: 6 July 2020; Accepted: 9 January 2021

\begin{abstract}
Climate change is causing changes in tree species performance and distribution, impacting breeding programme effectiveness. Our aim was to analyse the effects of provenance and climatic factors on the annual ring density of Masson pine (Pinus massoniana Lamb.) at different experimental sites and potential breeding strategies that may be developed in response to future climate change. The study trees represented provenances originating from the western, east-central, northern, and southern regions of $P$. massoniana distribution in China. The wood density differed significantly among provenances. A multisite variance analysis test showed that the type B correlation coefficients for ring density at the two sites studied were less than 0.8 , indicating an interaction effect of genotype by environment $(\mathrm{G} \times \mathrm{E})$ on tree ring density. Climatic factors directly affected the wood density properties. At Chun'an (CA), the maximum latewood density (MXD) and minimum earlywood density (MND) were positively correlated with absolute maximum temperatures in August and May of the current growing season, respectively. At Taizi Mountain (TZS), MXD was significantly positively correlated with absolute maximum temperature in September of the current year and significantly negatively correlated with precipitation in June. MND was significantly positively correlated with absolute maximum temperature in May of the current year and significantly negatively correlated with precipitation in April. The climatic effects on $P$. massoniana wood density differed among seed-source origins. This study showed that ring density characteristics differed significantly among provenances, and provenance selection could promote wood density. MXD and MND exhibited significant genotype-by-environment interaction effects, and significant correlations were found between ring density and temperature and precipitation conditions. These findings suggest that climatic factors and site conditions in addition to genetics could be strong drivers of wood density variation, and/or that wood density is a highly plastic trait.
\end{abstract}

Keywords: Pinus massoniana, provenance, climate change, wood density, radial growth

Addresses: Z. Zhang, G. Jin, Z. Zhou, Research Institute of Subtropical Forestry, Chinese Academy of Forestry, Daqiao Rd 73, Fuyang area, Hangzhou 311400, P. R. China, e-mail: zhenzh19860516@163.com; e-mail: zczhou_risf@163.com

Z. Feng, L. Sun. Laoshan Forest Farm of Chun'an Country, Zhejiang Province, Chun'an 311700, China ${ }^{*}$ Corresponding authors 


\section{Introduction}

Tree growth decline, wood quality decline and high tree mortality have been observed against the background of a changing climate, especially with continued warming and the emergence of extreme weather (Laura et al., 2017; Li et al., 2019). The sensitivity and plasticity of tree growth can be efficiently assessed through retrospective analyses of tree-ring density (RD), which is a widely applied proxy for wood quality (Sattler et al., 2015). Climate change is causing changes in tree species performance and distribution, impacting the effectiveness of breeding programmes. The effect of climatic factors on the radial increment has often been assessed through correlation analyses on standardized series of treering and meteorological variables (Zubizarreta-Gerendiain et al., 2012; Cai et al., 2017). Studies have primarily focused on the use of tree-ring width or ring density to reconstruct past temperature and precipitation changes. Moreover, the research sites have mostly been located in high-altitude and high-latitude areas, and there are few studies on the comprehensive response of tree-ring growth to climate in the subtropical regions of China (Chen et al., 2012a; Chen et al., 2015a; Cai et al., 2017). Masson pine (Pinus massoniana Lamb.) is the most widely distributed native coniferous species in subtropical China and is also one of the most widely grown plantation tree species. P. massoniana in China is distributed over latitudes ranging from $21^{\circ} 41^{\prime}-33^{\circ} 56^{\prime} \mathrm{N}$ and longitudes ranging from $102^{\circ} 10^{\prime}-123^{\circ} 14^{\prime} \mathrm{E}$ (Liu et al., 2010; Xiang et al., 2011; Li et al., 2019). This species has an extensive distribution range and spans many different environments, from humid and rainy along the coast to the colder and drier climates of the Qinling Mountains, where its populations have adapted to diverse environments; hence, selection of reproductive material could leverage the genetic diversity of this species to minimize the negative effects of the shifting climate. At the anatomical level, density is a function of cell size, shape and the thickness of the cell walls; as a comprehensive index of xylem cell wall thickness, the tree-ring density contains environmental information that cannot be obtained from the mean annual ring width (Wang et al., 2010; Chen et al., 2012b). Therefore, research on the influence of climate change on growth ring density of Masson pine for wood quality improvement and breeding strategy formulation is of the utmost importance (Chen et al., 2015b).

Provenance trials are established to assess the performance of diverse populations under certain environments. Provenance test results have shown the growth of $P$. massoniana to vary from provenance to provenance by $30.5 \%$ (Liu et al., 2009). Trees in the northern provenances grow more slowly and have better cold resistance than in the southern provenances at low latitude. Trees in the western provenances grow more slowly and have better drought resistance compared with the provenances in the east. The performance of the provenances is primarily evaluated based on yield, which indicates the suitability of the growing conditions over the entire life cycle of the trees. The rankings of the provenances change at different test sites, indicating that environmental conditions (altitude, soil, climate, etc) greatly impact the growth or adaptability of $P$. massonia$n a$ to different provenances. In general, differences in growth rate, shoot phenology and survival rate, which relate to adaptability, could be identified in early provenance tests (Nicotra et al., 2010; Taeger et al., 2015). However, the quality of wood from different provenances should be evaluated later during the growth period, because only long-term provenance tests can ensure that a forest site has experienced more extreme climatic and environmental conditions (Matisons et al., 2019). During the life of a tree, its sensitivity to environmental factors shifts due to both ageing (Zang et al., 2012) and the changing climate (Buntgen et al., 2006; Carrer \& Urbinati, 2006). Here, the degree of phenotypic change and adaptability becomes essential not only for investigators exploring species responses to the environment but also for those aiming to model the effects of the changing climate on species distributions (Valladares et al., 2006; Nicotra et al., 2010; Venegas-González et al., 2015). However, the comprehensive genetic and environmental influences on the wood quality of $P$. massoniana remain uncertain, and elucidation of these mechanisms will have important scientific value for guiding seed allocation planning.

Axial tracheids are the primary cells in coniferous wood; the tracheid size is the primary driver of the inter- and intra-annual variability of earlywood density, while the thickness of the cell walls is more influential for determining latewood density in conifer species (Bouriaud et al., 2005; Deslauriers \& Morin 2005; Seo et al., 2011; Pritzkow et al., 2014; Cuny et al., 2015). Some studies have shown that changes in temperature and precipitation significantly affect the ring width and ring density of conifers ( $\mathrm{Li}$ et al., 2019; Jiang et al., 2017). In particular, extreme weather has a considerable influence on the ring density of trees, greatly impacting the development of breeding programmes for major tree species. For example, the occurrence of extreme weather can cause the delay or advance of the tree growth season, and the density of early- or latewood will also fluctuate accordingly. Intra-annual density fluctuations (IADFs) reflect the changes in wood density during the growing season. It has been emphasized that IADFs may provide accurate information at the seasonal level, allowing a more detailed climate analysis within 
the growing season (Wang et al., 2006; Fuhrer et al., 2006; Schlyter et al., 2006; Lindner et al., 2010; Battipaglia et al., 2016). Research has primarily applied the relationship between the radial growth characteristics of trees and responses to climatic factors to reconstruct environmental changes in a given region or to project future climate change trends (Wang et al., 2010; Chen et al., 2012c). The drier and warmer conditions forecasted for many terrestrial ecosystems are likely to exert adverse effects on forest growth and survival, because tree populations may not be well adapted to the changing climate. Therefore, the selection of a well-adapted genotype under different provenance tests is crucial for improving wood quality of Masson pine trees planted over a wide area. To adapt forest management to climate change impacts, it is important to disentangle the effect of the environment from the effect of genetics on important traits such as wood density.

In P. massoniana, as in other tree species, the radial growth of the stem and the wood quality are influenced by the environment as well as by the genetic origin, and wood density is moderately to highly heritable (Zobel \& van Buijtenen, 1989; Hannrup et al., 2000; Liu et al., 2010). These genetic characteristics are usually investigated during the first half of the rotation period, before the optimal evaluation period for wood density has been reached. Growth rates affect wood density at different ages. For example, negative correlations between wood density and radial growth rate at early ages have been found in hybrid larch, although these relationships tended to be weaker with increasing age. Such selection at a young age is effective for wood density, but particular care must be taken in selecting trees with improved radial growth rate because rapid growth will result in a low-density wood product, especially rapid growth in the early growth period (Takaaki et al., 2006). Early evaluation of growth traits and wood density can improve the efficiency of selection for tree breeding. However, growth and development characteristics often differ significantly among provenances. Some provenances show rapid growth in the early stage, while others show typical growth in the early stage and rapid growth in the middle and late stage. Therefore, an important criterion for early selection is strong genetic correlation between the wood density of young and mature timber. Genetic age-age correlations are usually strong for wood density in coniferous species; however, genetic age-age correlations for growth have been found to be low (Hylen, 1995). The presence of age-age correlations clearly indicates that the same set of genes influences a wood density trait during juvenile and mature phases. Some research has shown the relative efficiency of selection for wood density to decrease with increasing age of selection, which may be related to the more stable wood density in older trees. For example, wood density has been shown in Pinus sylvestris to increase rapidly up to a tree age of approximately 25 years and stabilize thereafter at this level. This indicates that the wood formed at ages $28-33$ will be similar to the wood formed from these ages up to rotation age (Hannrup \& Ekberg, 1998). However, little information is available on the age-associated changes in genetic and phenotypic correlations in wood density in P. massoniana.

Future climate change may have different effects on the growth ring density of $P$. massoniana. Our aim was to revisit wood density data from provenance trials to understand the degree of genetic versus environmental control of wood density at the rotation age of $P$. massoniana. Our hypothesis is that if ring density is strongly affected by climatic conditions, then each provenance responds differently to climate. Therefore, during seed transfers, we can select germplasm according to the climatic conditions suitable for the growth of particular genotypes, ensure timber quality, and minimize the negative effects of climate change.

\section{Methods}

\section{Experimental sites and testing material}

The provenance experiments were set up in 1984 . One forest was located in Laoshan forest farm in the town of Chun'an $\left(29^{\circ} 33^{\prime} \mathrm{N}, 119^{\circ} 03^{\prime} \mathrm{E}\right.$; referred to as CA hereafter), Zhejiang province, and a total of 49 provenances from 14 provinces were tested in this forest. The test forest is $134 \mathrm{~m}$ above sea level, with a south-facing slope of less than 30 degrees. The experiment was established as a randomized complete block design of eight blocks, which were planted with a two-row layout (four trees per row) in each plot. The spacing of the initial planting was $2 \mathrm{~m} \times 2 \mathrm{~m}$. The other trial was in a forest at Taizi Mountain $\left(30^{\circ} 20^{\prime} \mathrm{N}, 114^{\circ} 18^{\prime} \mathrm{E}\right.$; referred to as TZS hereafter), Hubei Province (Fig. 1), and a total of 69 provenances were tested from the same number of provinces as in the CA test site. This test forest is $257 \mathrm{~m}$ above sea level, with a south-facing slope of less than 30 degrees. The experiment was established as a randomized complete block design of nine blocks and four-tree plots. The row spacing of the initial planting was $2 \mathrm{~m} \times 2 \mathrm{~m}$.

Mean monthly temperatures, mean maximum temperatures, mean minimum temperatures, and annual monthly precipitation in the research areas were obtained using data from the Chun'an $\left(29^{\circ} 37^{\prime} \mathrm{N}\right.$, $\left.119^{\circ} 01^{\prime} \mathrm{E}\right)$ and Taizi Mountains $\left(30^{\circ} 31^{\prime} \mathrm{N}, 114^{\circ} 07^{\prime} \mathrm{E}\right)$ meteorological stations from 1986-2016. The soil type of the TZS test site is yellow brown soil with a 


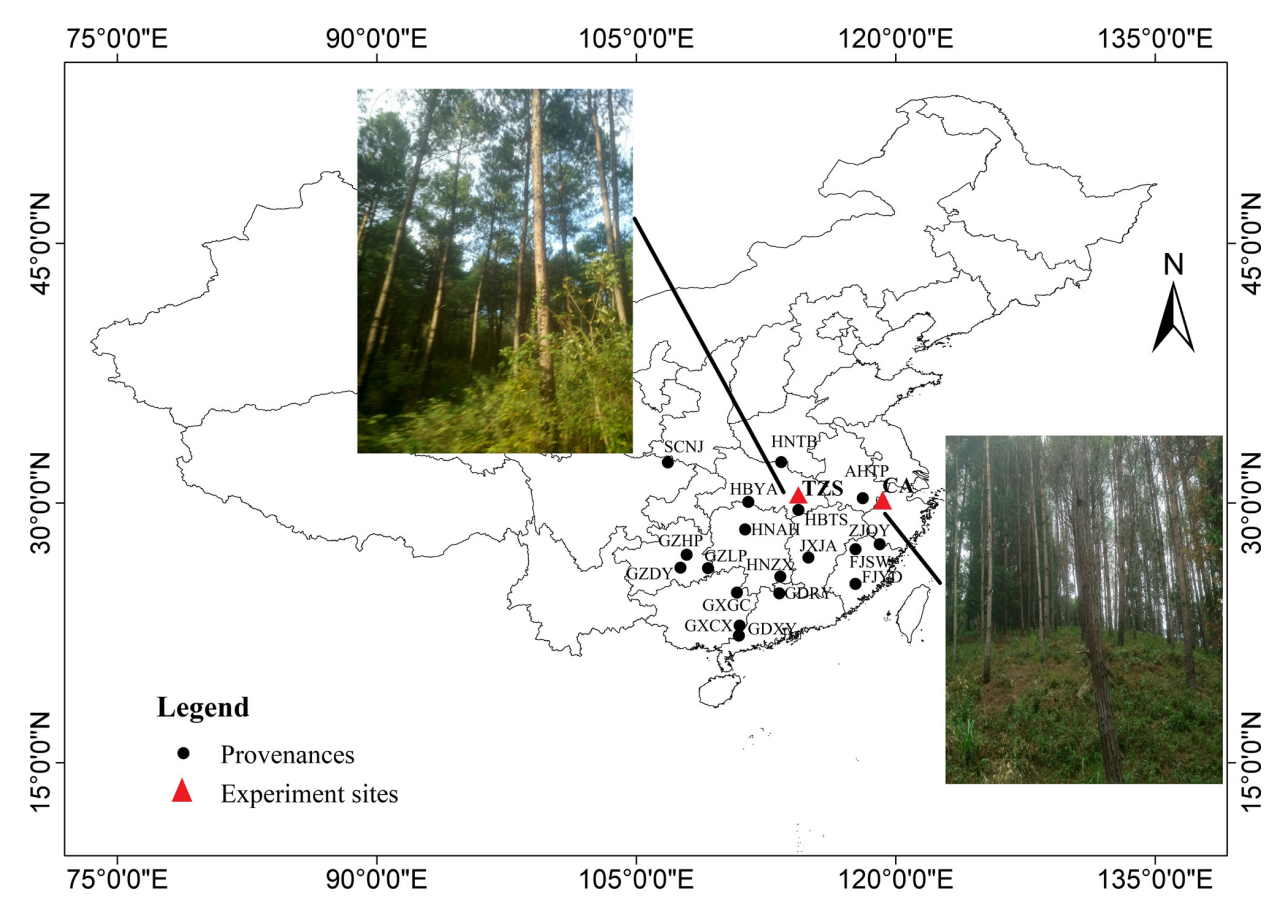

Fig. 1. Geographic locations of the origin of the studied P. massoniana provenances

$\mathrm{pH}$ of 6.15 . The soil type at the CA test site is a red soil with a $\mathrm{pH}$ of 4.55 . The TZS site is in a relatively arid area with an annual precipitation of $1090 \mathrm{~mm}$ and an annual mean temperature of $16.4^{\circ} \mathrm{C}$, whereas CA experiences annual precipitation of $1530 \mathrm{~mm}$ and an annual mean temperature of $17.2^{\circ} \mathrm{C}$. The warmest month in the two study areas is July, and the coldest month is January (Fig. 2).

The same 18 provenances were selected at each site, and they were sourced from the northern, east-central, southern, and western regions of the natural distribution range of $P$. massoniana, representing

Table 1. Statistical description of geographic coordinates, temperatures, and precipitation for the 18 provenances at the CA and TZS test sites

\begin{tabular}{|c|c|c|c|c|c|c|c|c|}
\hline Provenances & $\begin{array}{l}\text { Latitude } \\
(\mathrm{N})\end{array}$ & $\begin{array}{l}\text { Longitude } \\
\text { (E) }\end{array}$ & Region & $\begin{array}{c}\text { Mean annual } \\
\text { temperature } \\
\left({ }^{\circ} \mathrm{C}\right)\end{array}$ & $\begin{array}{l}\text { Mean maximum } \\
\text { temperatures in } \\
\text { July }\left({ }^{\circ} \mathrm{C}\right)\end{array}$ & $\begin{array}{l}\text { Mean minimum } \\
\text { temperatures in } \\
\text { January }\left({ }^{\circ} \mathrm{C}\right)\end{array}$ & $\begin{array}{l}\text { Precipitation } \\
\quad(\mathrm{mm})\end{array}$ & $\begin{array}{l}\text { Localization of } \\
\text { meteorological } \\
\text { stations }\end{array}$ \\
\hline GDXY & $22.35^{\circ}$ & $110.93^{\circ}$ & South & 22.9 & 35.5 & 15.0 & 1785 & $22.15^{\circ} \mathrm{E}, 110.54^{\circ} \mathrm{N}$ \\
\hline GXCX & $22.92^{\circ}$ & $110.97^{\circ}$ & South & 21.9 & 33.3 & 13.1 & 1762 & $22.72^{\circ} \mathrm{E}, 110.05^{\circ} \mathrm{N}$ \\
\hline GDRY & $24.78^{\circ}$ & $113.27^{\circ}$ & South & 20.4 & 35.2 & 10.2 & 1635 & $113.17^{\circ} \mathrm{E}, 24.47^{\circ} \mathrm{N}$ \\
\hline GXGC & $24.83^{\circ}$ & $110.82^{\circ}$ & South & 17.8 & 34.1 & 8.9 & 1752 & $110.49^{\circ} \mathrm{E}, 24.5^{\circ} \mathrm{N}$ \\
\hline FJYD & $25.33^{\circ}$ & $117.67^{\circ}$ & South & 20.4 & 33.6 & 10.8 & 1654 & $116.43^{\circ} \mathrm{E}, 24.44^{\circ} \mathrm{N}$ \\
\hline FJSW & $27.33^{\circ}$ & $117.67^{\circ}$ & South & 18.3 & 33.2 & 7.5 & 1888 & $117.28^{\circ} \mathrm{E}, 27.2^{\circ} \mathrm{N}$ \\
\hline GZLP & $26.23^{\circ}$ & $109.15^{\circ}$ & West & 16.7 & 31.2 & 5.5 & 1469 & $109.09^{\circ} \mathrm{E}, 26.14^{\circ} \mathrm{N}$ \\
\hline GZDY & $26.27^{\circ}$ & $107.55^{\circ}$ & West & 16.5 & 30.3 & 6.1 & 1153 & $107.32^{\circ} \mathrm{E}, 26.19^{\circ} \mathrm{N}$ \\
\hline GZHP & $26.95^{\circ}$ & $107.90^{\circ}$ & West & 16.2 & 31.0 & 4.8 & 1202 & $107.54^{\circ} \mathrm{E}, 26.54^{\circ} \mathrm{N}$ \\
\hline SCNJ & $32.35^{\circ}$ & $106.83^{\circ}$ & West & 16.1 & 31.2 & 5.9 & 1086 & $106.5^{\circ} \mathrm{E}, 32.21^{\circ} \mathrm{N}$ \\
\hline HNZX & $25.75^{\circ}$ & $113.33^{\circ}$ & $\begin{array}{l}\text { Central- } \\
\text { eastern }\end{array}$ & 18.6 & 33.9 & 6.5 & 1488 & $25.32^{\circ} \mathrm{E}, 112.78^{\circ} \mathrm{N}$ \\
\hline ZJQY & $27.62^{\circ}$ & $119.07^{\circ}$ & $\begin{array}{l}\text { Central- } \\
\text { eastern }\end{array}$ & 16.2 & 30.9 & 6.5 & 1787 & $27.51^{\circ} \mathrm{E}, 119.67^{\circ} \mathrm{N}$ \\
\hline JXJA & $27.08^{\circ}$ & $114.92^{\circ}$ & $\begin{array}{l}\text { Central- } \\
\text { eastern }\end{array}$ & 18.8 & 33.5 & 6.8 & 1549 & $27.32^{\circ} \mathrm{E}, 114.56^{\circ} \mathrm{N}$ \\
\hline HNAH & $28.47^{\circ}$ & $111.30^{\circ}$ & $\begin{array}{l}\text { Central- } \\
\text { eastern }\end{array}$ & 16.5 & 33.2 & 4.7 & 1741 & $28.66^{\circ} \mathrm{E}, 111.68^{\circ} \mathrm{N}$ \\
\hline HBTS & $29.60^{\circ}$ & $114.38^{\circ}$ & $\begin{array}{l}\text { Central- } \\
\text { eastern }\end{array}$ & 16.1 & 33.3 & 4.8 & 1525 & $29.86^{\circ} \mathrm{E}, 114.64^{\circ} \mathrm{N}$ \\
\hline HBYA & $30.07^{\circ}$ & $111.48^{\circ}$ & North & 15.9 & 32.2 & 5.0 & 1157 & $30.54^{\circ} \mathrm{E}, 111.81^{\circ} \mathrm{N}$ \\
\hline AHTP & $30.28^{\circ}$ & $118.10^{\circ}$ & North & 8.9 & 20.5 & -1.9 & 1866 & $30.21^{\circ} \mathrm{E}, 117.90^{\circ} \mathrm{N}$ \\
\hline HNTB & $32.37^{\circ}$ & $113.38^{\circ}$ & North & 14.3 & 32.2 & 1.6 & 924 & $32.23^{\circ} \mathrm{E}, 113.55^{\circ} \mathrm{N}$ \\
\hline
\end{tabular}



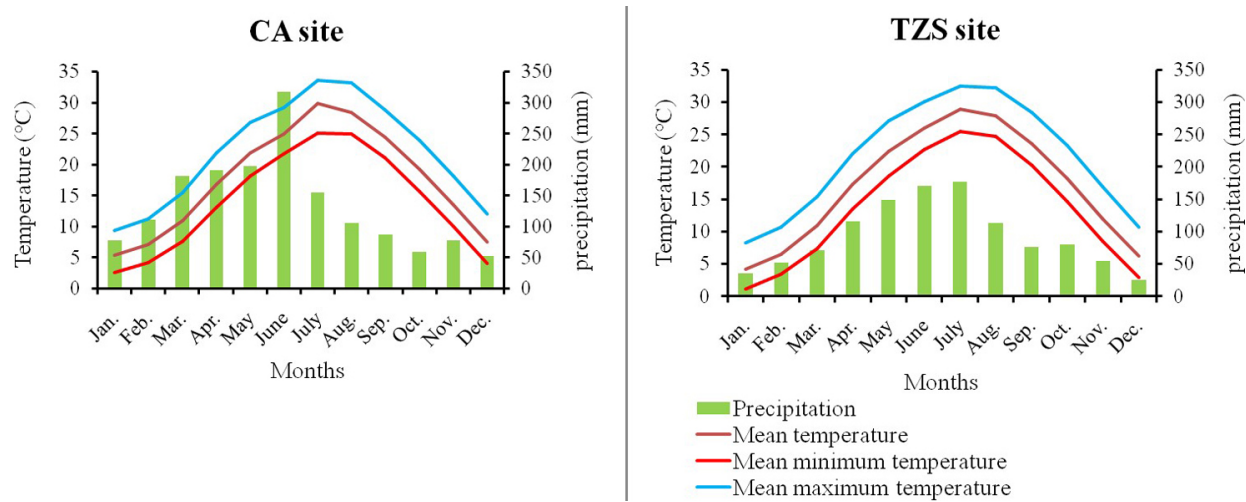

Fig. 2. Mean monthly temperature, mean maximum temperatures, mean minimum temperatures, and precipitation in the research area based on the Chun'an and Taizi Mountain meteorological stations during the period 1986-2016

different distributions of thermal and pluvial conditions (Table 1). The northern regions of the P. massoniana natural distribution area are primarily in the Dabie Mountains and Daba Mountains, the southern regions are largely distributed south of the Wuyi Mountains and Yunkai Mountains, the central-eastern regions are mostly distributed in the Wuyi Mountains and north of the Nanling Mountains, and the western regions are primarily distributed south of the Qinling and Hengduan Mountains (Liu et al., 2009).

\section{Sampling and data collection}

In November 2016, sampling was performed at the experimental forests in three blocks at two test sites. For each provenance, a total of six trees in three blocks were selected in each plot. A total of 216 trees were selected from the two sites, and $5.15-\mathrm{mm}$ cores were extracted from each tree at $1.3 \mathrm{~m}$ using an increment borer (Haglof, Stockholm, Sweden). To extract resins and other soluble components from the wood, thin laths were chemically treated with alcohol in a Soxhlet system for $48 \mathrm{~h}$ according to the standard procedure (Grabner et al., 2005). The cores were removed and dried. We obtained one radial X-ray density profile from the wood core using indirect X-ray densitometry. The samples were conditioned at $12 \%$ moisture content in a chamber with a temperature of $22^{\circ} \mathrm{C}$ and $66 \%$ relative humidity. Radiographic images were obtained using the following settings for the X-ray tube: voltage to $30 \mathrm{kV}$, current to $50 \mathrm{~mA}$, exposure time equal to $25 \mathrm{~min}$, scanning $20 \mu \mathrm{m}$ at a time. A 16-bit, grey level radiographic (X-ray) digital image was obtained for each sample at 1270 dpi resolution. Ring width and density indices were measured using WinDENDRO TM (WinDENDRO 2009c, Regent, Quebec, Canada) (density version) software. For each annual ring, the following variables were obtained from the corresponding density profile: earlywood width (EW), latewood width (LW), minimum earlywood density (MND), and maximum latewood density (MXD).

\section{Ring width and ring density characteristics}

In this analysis, cores from the same tree were treated separately to maximize climatic signal, because averaging tree core values may decrease the signal-to-noise ratio. The quality of a measured series of ring widths was checked by graphical and statistical crossdating, using the COFECHA program (Holmes, 1983). The results showed that the primary data series covered 30 years from 1987 to 2016 (from the most recently formed inward). The ring width and ring density are not only affected by environmental and ecological factors but also controlled by their own physiological factors; therefore, to remove potentially non-climatically induced low- and medium-term growth trends, each individual raw data series was transformed into a growth index series. All the tree-ring series (EW, LW, MND, and MXD) were detrended by applying a cubic smoothing spline with a $50 \%$ frequency response cut-off at $67 \%$ for each individual series length. Standardization was performed using the ARSTAN program. To receive a clear annual climate signal, the remaining autocorrelation was removed by autoregressive modelling, and we therefore used the residual chronological variation for further analyses (Schneider et al., 2008). The mean sensitivity (MS), interseries correlation, first order autocorrelation (AC), signal-to-noise ratio (SNR), and expressed population signal (EPS) were calculated to describe the datasets. We performed principal component analysis (PCA) of width and density characteristics (Chen et al., 2015a).

\section{Relationship between climate and tree- ring data}

The relationships between the tree-ring indices and the climatic data were analysed using the program DENDROCLIM2002 (Biondi \& Waikul, 2004). Because the growth of a tree may be affected not only 
by the climatic conditions of the current growing season but also by those of the previous growing season (Chen et al., 2015a), both the previous and the current growing seasons were included in the climate correlation analysis. We chose to calculate correlation coefficients instead of response functions, because we were interested in the magnitude and direction of each relationship rather than a simulation of the relationships for the experimental site. The climate data used for the analysis included total monthly precipitation, mean monthly temperature and mean maximum and minimum temperatures over a span of 12 months (the previous November to the current October). Climate data near the seed-source origins were downloaded from the China Meteorological Science data sharing service network (http://cdc.cma.gov.cn).

\section{Variance analysis}

Mixed linear models were used to test for significant differences in the wood density characteristics among sites and provenances. Each wood density characteristic for each year was tested separately. An analysis of variance (ANOVA) was performed using the following model:

$$
y_{i j k l m}=u+S_{i}+B_{j(i)}+\underset{(\text { Eq. 1) }}{A_{m}+P_{k}+P^{*} S_{i k}+P^{*} A_{k m}+e_{i j k l m}}
$$

where $y_{i j k l m}$ represents the value of the $m$ th year for the $l$ th tree of the $k$ th provenance growing at the $j$ th block within the $i$ th site; $A_{m}, S_{i}, B_{j(i)}, P_{k}, P^{*} S_{i k}, P^{*} A_{k m,}$ and $e_{i k k m}$ represent the effects of the $m$ th tree age, the $i$ th site, the $j$ th block within the $i$ th site, the $k$ th provenance, the interaction between the $i$ th site and the $k$ th provenance, the interaction between the $m$ th tree age and the $k$ th provenance, and the error, respectively. All the factors were treated as fixed except $B_{j(i)}$ and $e_{i j k m}$. Preliminary analyses suggested that the plot (provenance-by-block interactions and tree ageby-block interactions) effects could be ignored and dropped from the model. To remove the heterogeneity between the sites and ensure high homogeneity of wood between test points, the model was fitted by including the repeated statement with the group option. The least square means of provenances were estimated using the estimate function. Note that here and elsewhere in the text, except where otherwise indicated, the term "significant" indicates $\mathrm{p}<0.05$.

\section{Genetic parameter description}

The phenotypic variation coefficient was calculated as follows:

$$
P C V=\frac{\delta}{X} \times 100 \%
$$

The genetic variation coefficient was calculated as follows:

$$
G C V=\frac{\sqrt{\delta_{g}^{2}}}{\bar{X}} \times 100 \%
$$

where PCV is the phenotypic coefficient of variation, $\delta$ is the standard deviation of each character, GCV is the genetic coefficient of variation, $\sqrt{\delta_{g}^{2}}$ is the genetic variance, and $\bar{X}$ is the mean value of the measured trait.

Type B genetic correlations were estimated as:

$$
r_{B}=\frac{\operatorname{cov}(g i, g j)}{\sqrt{\delta_{g i}^{2} \delta_{g j}^{2}}}
$$

where $\operatorname{cov}\left(g_{i}, g_{j}\right)$ is the covariance between site $i$ and $j$, and $\delta_{g i}^{2}$ and $\delta_{g j}^{2}$ are the variances at sites $i$ and $j$, respectively.

To interpret the genotype $\times$ environment interaction effect, a GGE biplot was created using the $\mathrm{R}$ software package GGE Biplot GUI (Ling et al., 2021).

\section{Model development}

The variables included in the wood density models included earlywood and latewood width, tree age, and climate. The site effect was not added to the models, although models were constructed separately for the two sites (Model ${ }_{\text {(CA) }}$ and Model ${ }_{\text {(TZS) }}$ ). The analyses were performed using the STAT package in SAS software. The climate variables that were most strongly correlated with the wood density characteristics were used to test the effect of climate on the wood density characteristics while controlling for radial growth. The linear mixed model of the density characteristic $\left(X_{m l k j}\right)\left(\mathrm{g} / \mathrm{cm}^{3}\right)$ in year $m$ for tree $l$ in provenance $p$ in block $j$ with ring width (EW or LW) $A_{1 m l k j}(\mathrm{~mm})$, tree age $A_{2 m l k j}$ (years), their interaction $\left(A_{1} A_{2}\right)_{m l k j}$, and climate variables $v_{1 y}$ and $v_{2 y}$ was:

$$
\begin{array}{r}
X_{m l k j}=\left(Q_{0}+q_{0 l}\right)+\left(Q_{1}+q_{11}\right) A_{1 m l k j}+\left(Q_{2}+q_{2 l}\right) A_{2 m l k j}+ \\
\left(Q_{3}+q_{3 l}\right)\left(A_{1} A_{2}\right)_{m l k j}+\left(Q_{4}+q_{4 l}\right) v_{1 y}+\left(Q_{5}+q_{5 l}\right) v_{2 y}+e_{m l k j} \\
q_{l}=\left\{q_{0 l}, q_{11}, q_{2 l}, q_{3 l}, q_{4 l}, q_{5 l}\right\} \sim N\left\{0,\left(d_{0}^{2}, d_{1}^{2}, d_{2}^{2}, d_{3}^{2}, d_{4}^{2},\right.\right. \\
\left.\left.d_{5}^{2}\right)\right\}, e_{m l k j} \sim N\left(0, d^{2}\right)
\end{array}
$$

where $Q_{0}, Q_{1}, Q_{2}, Q_{3}, Q_{4}$, and $Q_{5}$ are the fixed effects for the intercept and slopes of the dependent variables; $q_{l}$ is the random effect vector; and $e_{m l k j}$ is the within-group error. The error effects and random effects are normally distributed with zero mean, equal variance, and variances of $d_{0}{ }^{2}, d_{1}{ }^{2}, d_{2}{ }^{2}, d_{3}{ }^{2}, d_{4}{ }^{2}, d_{5}^{2}$, and $d^{2}$. We also tested whether the residual distribution of the model conformed to a normal distribution. 
The block effect was not included in these models because the variation explained by the block effect was close to zero. We also used an autoregressive model (autoreg program in the SAS/EUS module) to account for the residual autocorrelations and to eliminate the seasonal effects in the sample (Koubaa et al., 2005). The best model was chosen based on the Akaike information criterion (AIC), the Bayesian information criterion (BIC), and the -2-log likelihood test (Schwarz, 1978; Sakamoto et al., 1986; Searle et al., 1992).

\section{Results}

\section{Site and provenance effects on growth and density}

The phenotypic variation coefficients for the width and density of the annual ring were much higher than the coefficients of genetic variation (Table 2). The genetic variation coefficient of the annual ring density at the TZS test site exceeded the value for the CA test site. Compared with the GCV at a single site, the joint-site GCV values for MXD and MND in the test provenances were significantly lower.

There were significant differences in earlywood and latewood widths between the two sites $(\mathrm{p}<0.01)$. For ring density, the mean MND and MXD values of $P$. massoniana at the CA site were $88 \mathrm{~kg} \cdot \mathrm{m}^{-3}$ and $386 \mathrm{~kg} \cdot \mathrm{m}^{-3}$, respectively, and the mean MND and MXD at the TZS site were $93 \mathrm{~kg} \cdot \mathrm{m}^{-3}$ and $392 \mathrm{~kg} \cdot \mathrm{m}^{-3}$, respectively (Table S1).

The mean EW and LW for the AHTP provenance closest to the CA site were $27.8 \%$ and $12.3 \%$ lower, respectively, than those of the provenance with the highest EW and LW values (GXCX). The mean EW and LW of the HBTS provenance closest to the TZS site were $33.9 \%$ and $41.4 \%$ lower, respectively, than those of the provenances with the highest values (GXGC and GXCX). The mean MND and MXD of the AHTP provenance closest to the CA site were $39.6 \%$ and $23.2 \%$ lower, respectively, than those of the provenance with the highest values (GZHP). The mean MND and MXD of the HBTS provenance closest to the TZS site were $19.8 \%$ and $11.4 \%$ lower, respectively, than those of the provenances with the highest values (FJYD and SCNJ).

\section{Evaluation of stability and adaptability}

The type B correlation coefficient is often used to analyse $\mathrm{G} \times \mathrm{E}$ effects of tree provenances or families and sites. The correlation coefficients for MXD and MND between CA and TZS ranged between 0.32 and 0.7 (Fig. 3), less than 0.8, indicating that MXD and MND had significant genotype-by-environment interaction effects (Ling et al., 2021). This finding shows that it is necessary to select the provenance that is suitable for a specific environment to reap the potential benefits.

Fig. 4 indicates the best provenance for dividing the test point group and each test point. The provenances farthest from the origin in each direction are connected to form a polygon. The GGE biplot is

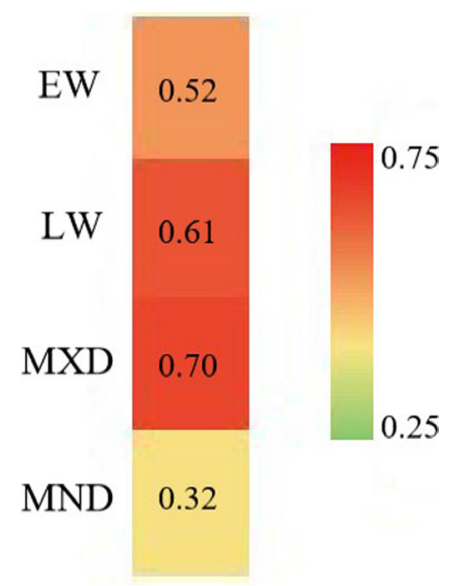

Fig. 3. Type B correlation coefficient of tree-ring width and tree-ring density at two sites

Table 2. Descriptive statistics of the studied datasets of tree-ring width and tree-ring density for the common period from 1987 to 2016

\begin{tabular}{|c|c|c|c|c|}
\hline Test sites & Traits & Mean & PCV (\%) & GCV (\%) \\
\hline \multirow[t]{4}{*}{ Chun'an (CA) } & $\mathrm{EW}(\mathrm{mm})$ & 1.98 & 42.98 & 15.79 \\
\hline & LW (mm) & 1.88 & 39.70 & 14.50 \\
\hline & $\operatorname{MND}\left(\mathrm{kg} \cdot \mathrm{m}^{-3}\right)$ & 89.61 & 12.66 & 4.43 \\
\hline & $\operatorname{MXD}\left(\mathrm{kg} \cdot \mathrm{m}^{-3}\right)$ & 381.00 & 12.45 & 3.81 \\
\hline \multirow{4}{*}{$\begin{array}{l}\text { Taizishan Mountain } \\
\text { (TZS) }\end{array}$} & EW (mm) & 1.96 & 39.51 & 17.73 \\
\hline & LW (mm) & 1.50 & 41.52 & 17.02 \\
\hline & $\operatorname{MND}\left(\mathrm{kg} \cdot \mathrm{m}^{-3}\right)$ & 87.39 & 11.97 & 5.00 \\
\hline & $\operatorname{MXD}\left(\mathrm{kg} \cdot \mathrm{m}^{-3}\right)$ & 388.83 & 12.15 & 5.29 \\
\hline \multirow[t]{4}{*}{ Joint-site } & $\mathrm{EW}(\mathrm{mm})$ & 1.97 & 43.21 & 12.36 \\
\hline & LW (mm) & 1.76 & 41.72 & 10.89 \\
\hline & $\operatorname{MND}\left(\mathrm{kg} \cdot \mathrm{m}^{-3}\right)$ & 88.50 & 13.24 & 4.04 \\
\hline & $\operatorname{MXD}\left(\mathrm{kg} \cdot \mathrm{m}^{-3}\right)$ & 384.91 & 12.05 & 3.16 \\
\hline
\end{tabular}



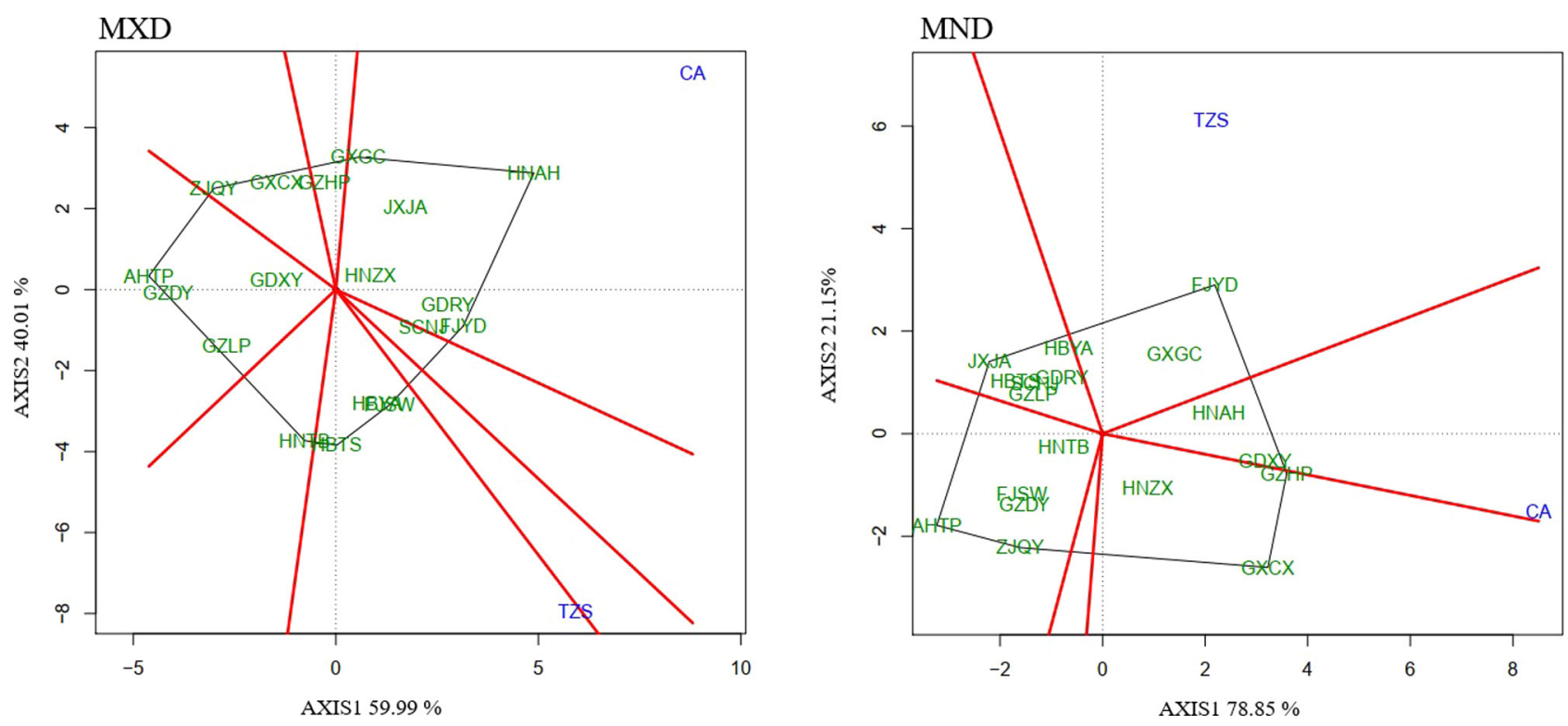

Fig. 4. Which-won-where GGE biplot with genetic effects of 18 Pinus massoniana provenances tested at two sites

MXD

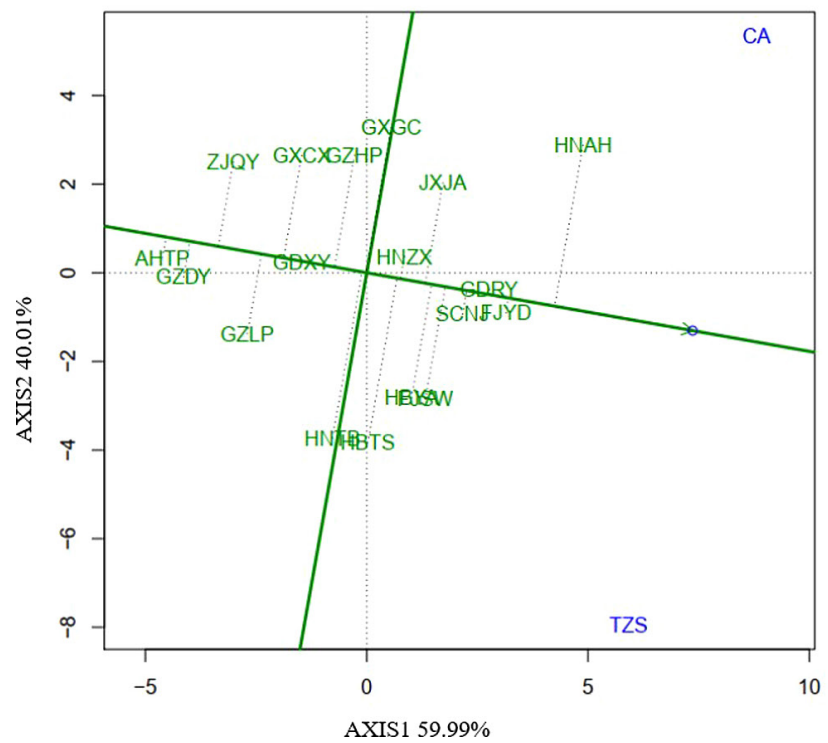

MND

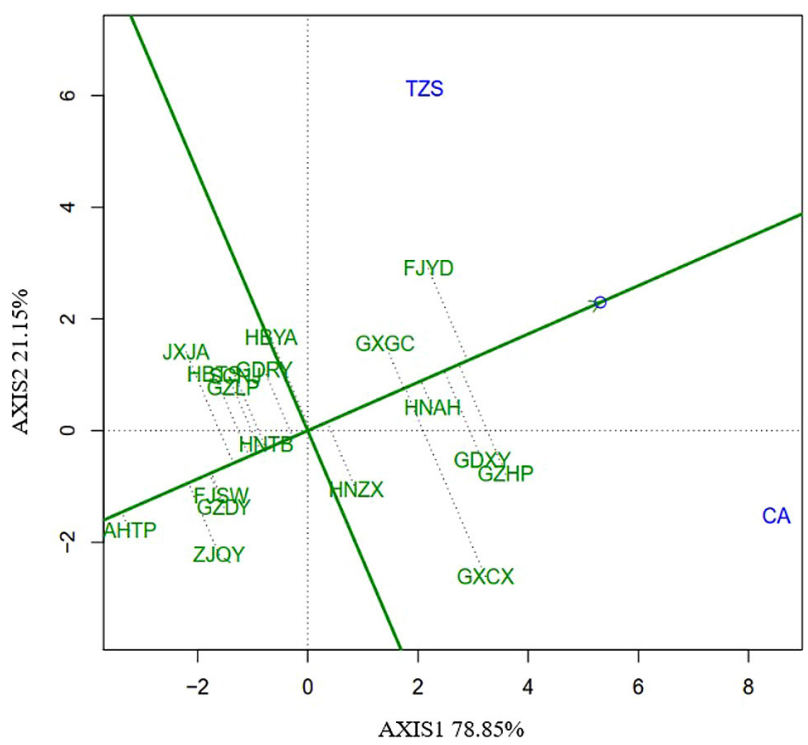

Fig. 5. Mean vs. Stability GGE biplot with genetic effects of 18 Pinus massoniana provenances tested at two sites

divided into several sectors by drawing vertical lines to each side through the origin. Two points are divided into two different sectors. The provenance at the top corner of the polygon in each sector is the best provenance contained in the test point within the sector (Braga et al., 2020). In terms of MXD, the HNAH, SCNJ, FJYD and GDRY provenances performed better at the CA test site, and the HBTS, FJSW and HBYA provenances performed better at the TZS test sites. Similarly, for MND, the TZS test site location exhibited favourable performance for FJYD and GXGC provenances, and the sectors at the CA test point featured high-performing HNAH, GDXY, and GZHP provenances. Provenances located inside the polygons, close to the origin, are insensitive to changes at a test site.
Fig. 5 reflects high yield and stability of ring density for the participating provenances. The closer the vertical line of a provenance to the average ambient axis, the further it is in the positive direction, indicating a high value for the source. The length of the dotted line perpendicular to the average ambient axis indicates the stability of the density, and the longer the vertical dotted line, the less stable the density. The MXDs of the HNAH, GDRY, FJYD, and SCNJ provenances were large; however, the MXD of HNAH provenance was the greatest but unstable. The MNDs of the FJYD, GZHP, GDXY, GXGC and HNAH provenances were large, but performance was unstable between the test points. In addition, the AHTP provenance exhibited smaller annual ring density characteristics at the two test points. 


\section{Relationships between tree growth and climate}

Considering that trials were ongoing, and the stands have been thinned, the numbers of trees available for sampling were limited. However, it was possible to achieve an acceptable degree of synchronization within the tree ring series (Table 3). Tree-ring width chronologies exhibited relatively low mean sensitivities (MS, 0.09-0.12) and standard deviations (SD, 0.16-0.25). These data indicate rather moderate interannual variation in the EW and LW series. The expressed population signal (EPS, 0.94-0.98) and variances in the first eigenvector (PC1, 30.2-46.6\%) indicate that growth responded to common factors in different trees. The MND and MXD chronologies had lower SNRs and EPSs than did the tree-ring width chronologies. The wood density indices exhibited low year-to-year variability, as emphasized by the low mean sensitivities $(0.04-0.06)$ and the standard deviations (0.06-0.08).

The individual chronologies of MND and MXD were highly correlated among the diverse provenances, indicating that similar climatic factors affected the high-frequency variations in each wood density characteristic (Figure S1). The correlation coefficients of the individual residual chronologies and average-provenance residual chronologies varied

Table 3. Descriptive statistics for the residual chronologies in the Chun'an and Taizi mountains test sites

\begin{tabular}{cccccccc}
\hline Site & Type of parameter & MS & SD & SNR & R & EPS & PC1 \\
\hline CA & EW & 0.12 & 0.25 & 21.41 & 0.61 & 0.97 & 30.2 \\
& LW & 0.09 & 0.19 & 17.18 & 0.52 & 0.98 & 34.1 \\
& MND & 0.04 & 0.07 & 11.30 & 0.79 & 0.85 & 33.2 \\
& MXD & 0.06 & 0.08 & 12.53 & 0.74 & 0.88 & 36.5 \\
& EW & 0.12 & 0.16 & 32.20 & 0.54 & 0.98 & 38.6 \\
& LW & 0.11 & 0.18 & 21.71 & 0.47 & 0.94 & 46.6 \\
& MND & 0.05 & 0.06 & 10.72 & 0.75 & 0.88 & 31.3 \\
& MXD & 0.05 & 0.07 & 13.31 & 0.64 & 0.87 & 32.1 \\
\hline
\end{tabular}

EW - early wood width; LW - late wood width; MND - minimum early wood density; MXD - maximum late wood density; MS - the mean sensitivity; SD - the standard deviation; SNR - the signal-to noise ratio; R - mean correlation among series; EPS - the expressed population signal; PC1 - the frst principal components.
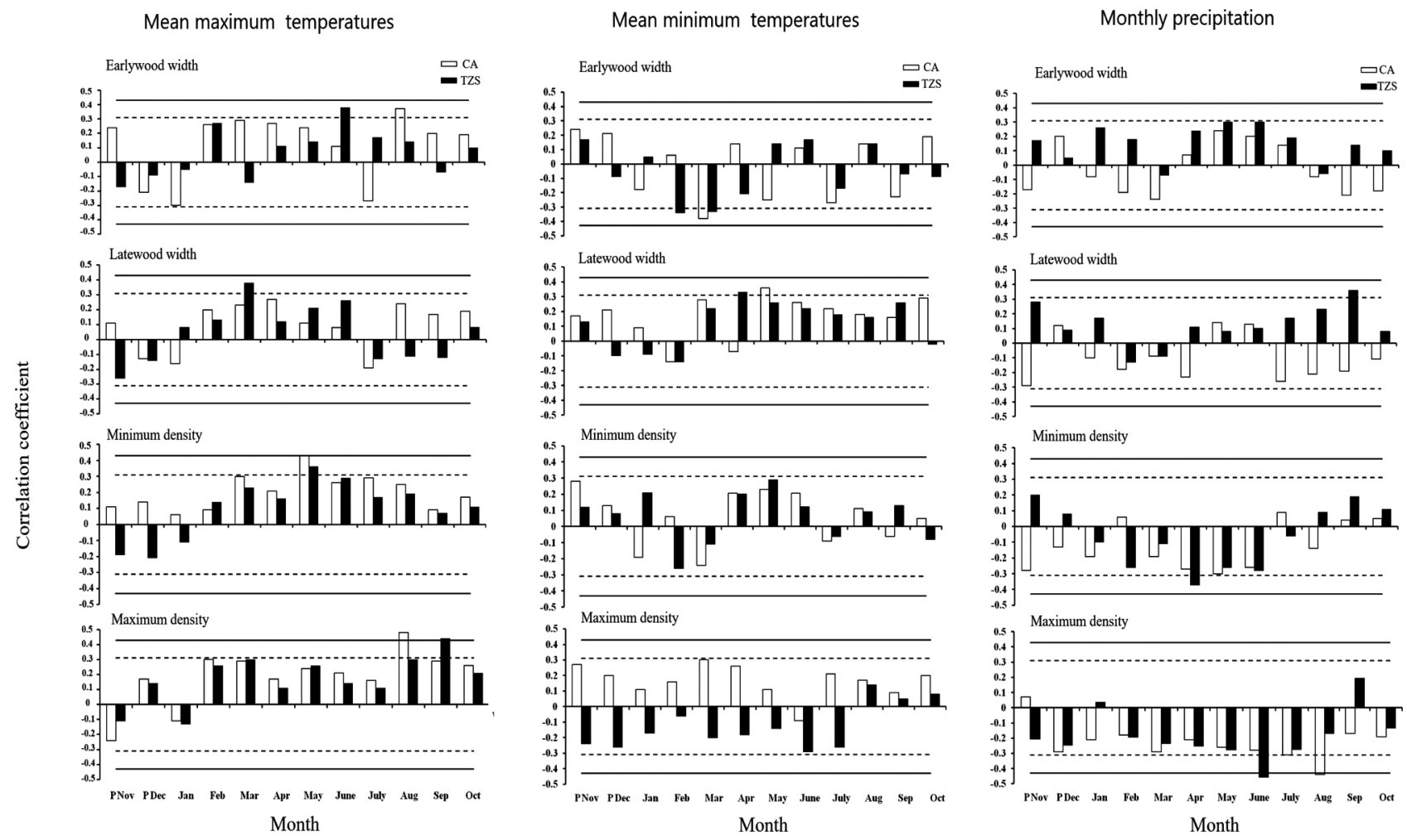

Fig. 6. Correlation coefficients relating mean maximum monthly temperature, mean minimum monthly temperature and precipitation to average earlywood and latewood chronologies of $P$. massoniana provenances for 1986-2016. Dashed and solid horizontal lines indicate $\mathrm{P}<0.05$ and $\mathrm{P}<0.01$, respectively. Correlation coefficients were calculated for 12 months from November of the previous growth year (pNov-pDec) to October of the current growth year (Jan-Oct) 
from 0.69 to 0.87 for MND and from 0.59 to 0.85 for MXD, reflecting a common climatic signal in the density chronologies of the diverse populations.

At the CA site, the MND was positively correlated with the mean maximum monthly temperature in May and significantly negatively correlated with precipitation in May of the current growing season (Fig. 6). The MXD was positively correlated with the mean maximum monthly temperature in August and significantly negatively correlated with precipitation in August of the current growing season. At the TZS site, MND was significantly positively correlated with the mean maximum monthly temperature in May and significantly negatively correlated with precipitation in April of the current year. The MXD was significantly positively correlated with the mean maximum monthly temperature in September and was significantly negatively correlated with precipitation in June of the current year. In addition, the correlations between mean minimum temperature and MXD and MND were not significant at either experimental site.

\section{Model development and predictive analysis}

Climatic variables were included in the annual ring density characteristic model, and the model represented the significant effects of tree-ring width (EW or LW), climate, and its interaction on MXD and MND (Table 4). The effect of EW on MND was negative, and the effect of LW on MXD was positive. The interaction between radial growth and tree age exerted positive effects on MND and MXD. The climate effect was significant in the model $(p<0.001)$, indicating that wood density was strongly influenced by climate.

Random variation among trees in the intercept explained from 6.09 to $7.16 \%$ of the variation relative to the fixed effect of the intercept for the average values of MND and MXD at the two test sites. Values of random between-tree variation were high for the estimated LW/EW effect, ranging from 31.5 to $44.7 \%$ for MND and MXD, with the age effect showing the highest values; i.e., from 44.2 to $61.3 \%$. The random variation in the interaction term ranged from 12.2 to $18.1 \%$ for MND and MXD. The random variation in the climatic variables was high only for MXD, from 25.2 to $31.3 \%$ at the two test sites.

As shown in Fig. 7, estimates of minimum earlywood density and maximum latewood density by the model were correlated with the actual observed values for density, generally showing a high degree of fit. The maximum latewood density and the minimum earlywood density of the seed-source origins were predicted under the same climatic conditions as were present at the planting site (Fig. 8). The

Table 4. Variance composition, parameter estimation, and fitting statistics of different models, standard errors of the estimates are in parentheses

\begin{tabular}{|c|c|c|c|c|}
\hline \multirow{2}{*}{ Coefficient } & \multicolumn{2}{|c|}{ Maximum density $\left(\mathrm{kg} \cdot \mathrm{m}^{-3}\right)$} & \multicolumn{2}{|c|}{ Minimum density $\left(\mathrm{kg} \cdot \mathrm{m}^{-3}\right)$} \\
\hline & Model $_{(\mathrm{CA})}$ & $\operatorname{Model}_{(\mathrm{TZS})}$ & Model $_{(\mathrm{CA})}$ & Model $_{(\mathrm{TZS})}$ \\
\hline \multicolumn{5}{|c|}{ Fixed effects parameters } \\
\hline$Q_{0}$ & $0.6427(0.0049)$ & $0.6021(0.0051)$ & $0.5829(0.0063)$ & $0.6719(0.0071)$ \\
\hline$Q_{1}$ & $0.0107(0.0015)$ & $0.0138(0.0013)$ & $-0.0202(0.0011)$ & $-0.0196(0.0019)$ \\
\hline$Q_{2}$ & $0.0031(0.0004)$ & $0.0058(0.0003)$ & $0.0012(0.0004)$ & $0.0031(0.0003)$ \\
\hline$Q_{3}$ & $0.0009(0.0002)$ & $0.0008(0.0002)$ & $0.0008(0.0001)$ & $0.0011(0.0003)$ \\
\hline$Q_{4}$ & $0.0041(0.0004)$ & $0.0053(0.0005)$ & $0.0073(0.0005)$ & $0.0057(0.0003)$ \\
\hline$Q_{5}$ & $-0.0063(0.0005)$ & $-0.0066(0.0005)$ & & $-0.0051(0.0005)$ \\
\hline \multicolumn{5}{|c|}{ Random effects parameters } \\
\hline$q_{0}$ & 0.0420 & 0.0367 & 0.0390 & 0.0481 \\
\hline$q_{1}$ & 0.0036 & 0.0043 & 0.0070 & 0.0088 \\
\hline$q_{2}$ & 0.0014 & 0.0033 & 0.0007 & 0.0014 \\
\hline$q_{3}$ & 0.0001 & 0.0001 & 0.0001 & 0.0001 \\
\hline$q_{4}$ & 0.0011 & 0.0016 & 0.0013 & 0.0008 \\
\hline$q_{5}$ & 0.0016 & 0.0020 & & 0.0005 \\
\hline Residual & 0.0776 & 0.0685 & 0.0856 & 0.0801 \\
\hline-2 log likelihood & 9675 & 10187 & 9314 & 8146 \\
\hline Akaike Information Criterion & 9637 & 10171 & 9302 & 8098 \\
\hline Bayesian Information Criterion & 9696 & 10204 & 9386 & 8129 \\
\hline
\end{tabular}

$Q_{0}$ are the fixed effects for the intercept of the dependent variables; $Q_{1}$ are the fixed effects for the slopes of ring width (EW or LW); $Q_{2}$ are the fixed effects for the slopes of tree age; $Q_{3}$ are the fixed effects for the slopes of interaction between ring width and tree age; $Q_{4}$ and $Q_{5}$ are the fixed effects for the slopes of climate variables; $q 0$ are the random effect for the intercept of the dependent variables; $q 1$ are the random effect for the slopes of ring width (EW or LW); $q_{2}$ are the random effect for the slopes of tree age; $q_{3}$ are the random effect for the slopes of interaction between ring width and tree age; $q_{4}$ and $q_{5}$ are the random effect for the slopes of climate variables. 

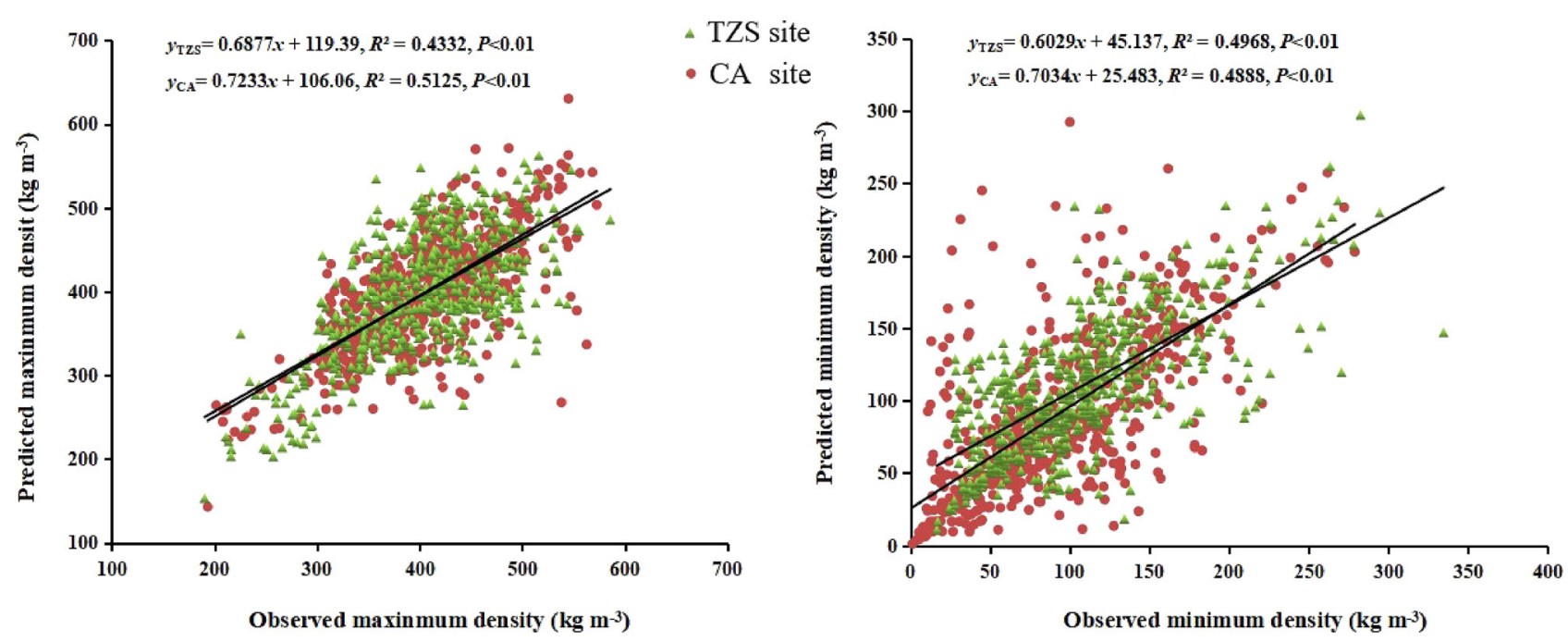

Fig. 7. Predicted values of MXD and MND plotted versus observed values of $P$. massoniana provenances from the Chun'an and Taizi Mountain test sites using the formulated model
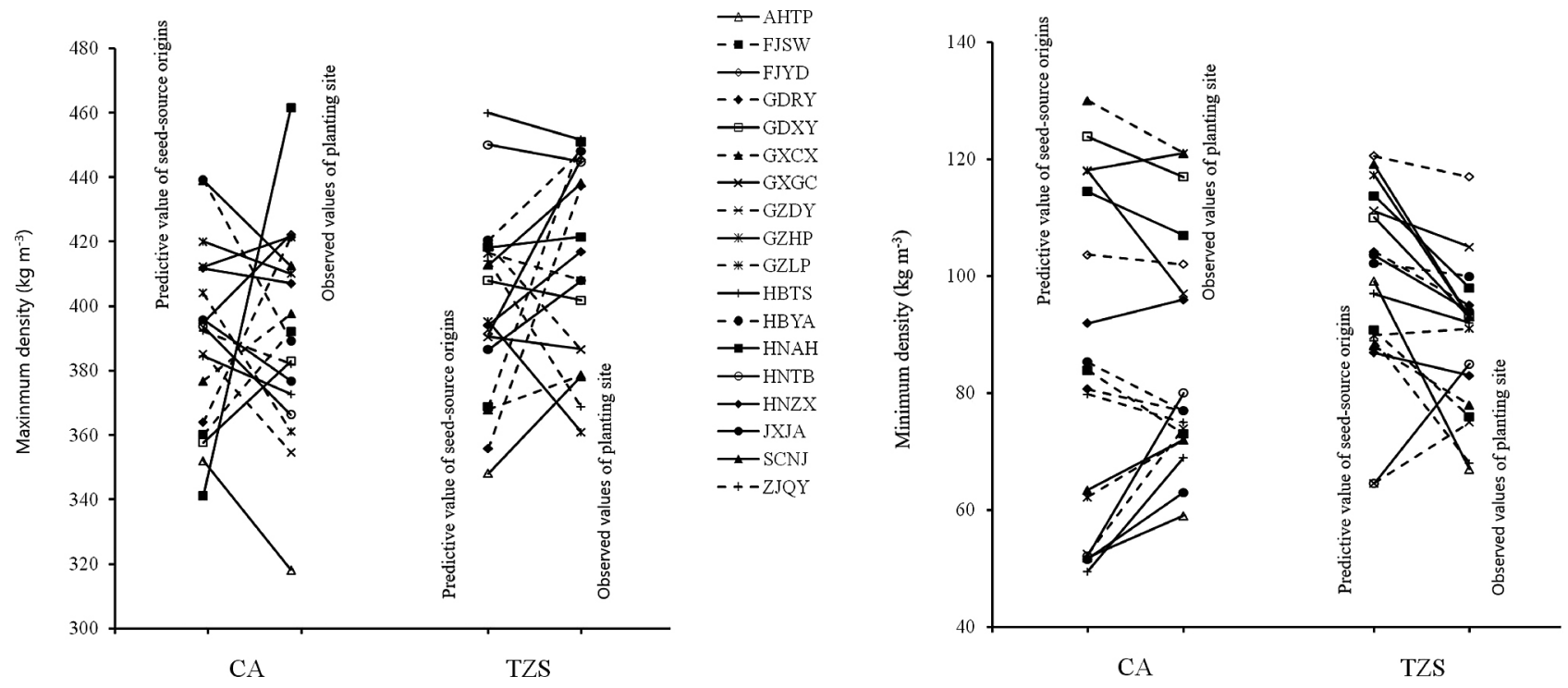

Fig. 8. Predicted variations in the wood density characteristics according to the climate effect model at each seed-source origin, and compared with the wood density values at the Chun'an and Taizi Mountains sites

results indicate that the mean MXD of most southern seed-source origins, such as FJSW, FJYD, GDRY, GXGC, GDXX, and GXCX, were lower than those for the planting sites. For relatively cold and dry seedsource origins, such as GZHP, GZDY, GZLP, HBYA, HNTB, and other provenances, the predicted mean MXD values were higher than values at the planting sites. The mean MXD predicted for the AHTP seedsource origin was lower than that of the planting site. Mean MND showed a trend opposite to that for mean MXD.

\section{Discussion}

Wood density is considered a heritable trait with a strong phylogenetic signal, and it is driven by climate
(George et al., 2017; Nabais et al., 2018; Klisz et al., 2019; Buras et al., 2020). Our analyses show clear effects of provenances on MXD and the MND, and genetic improvement of tree-ring density in P. massoniana has great potential use in selection. MXD is the growth variable most sensitive to climatic conditions (Camarero \& Gutiérrez, 2017). At the CA site, the MXD values for the western provenances were greater than those of the northern, east-central, and southern regions. At the TZS site, MXD was the highest for the western and central provenances, and these values were greater than the values for the northern and southern provenances (Table 1S). In addition, there was significant interaction between genotype and environment. Therefore, we used a GGE biplot to select the better performing sources for each test point and evaluate their stability and adaptability. The HNAH 
provenance only showed high MXD, with very weak stability. The GDRY, SCNJ, and FJYD provenances exhibited not only high MXD but also good stability, indicating that the trees of these provenances feature favourable adaptability. This study determined that the SCNJ, FJYD and GDRY provenances may be better adapted to CA, while the FJSW and HBYA provenances were more suitable for TZS.

The wood density variation of the provenances in the provenance trials was associated with the climatic conditions of the place of origin (Table S2). When the western and central provenances were planted at the CA site, the relatively warm and humid climatic conditions of this site benefited the continued formation of latewood because of the abundant precipitation and relatively high temperatures during the late growing season. Therefore, the MXD at this site was relatively high. The experimental site at TZS had a relatively dry climate, which was similar to conditions at the places of origin of the western and central provenances. Because the summer precipitation at this site was relatively low and the temperatures during the late summer and early fall were also relatively low, the growth of the southern provenances was suppressed (Zang et al., 2012). At this site, the northern provenance AHTP was an exception, which could be related to the abundant precipitation in the AHTP seed-source origin (Nabais et al., 2018). This explanation is also supported by the relationship between annual ring density and the environmental variables of the seed source, the finding that performance at the TZS test point is more related to precipitation at the place of origin of a provenance (Table S2), and the observation that annual ring density has adapted to the source origin environment.

At the TZS site, the temperature influenced the wood density, although precipitation also had relatively large effects on wood density. MXD was significantly positively correlated with the average maximum temperature in September of the current year and significantly negatively correlated with the precipitation in June. MND was significantly positively correlated with the average maximum temperature in May of the current year and significantly negatively correlated with precipitation in May. The precipitation from June to August was $410 \mathrm{~mm}$, and the relatively dry soil conditions limited the growth of P. massoniana at the TZS site. Particularly in June and July, a period of rapid tree growth, the high summer temperatures can greatly reduce soil moisture, thereby affecting tree growth (Vitasse et al., 2011; Kapeller et al., 2012). Studies have shown that for both $P$. resinosa and $P$. banksiana, increases in earlyand latewood density are related to drought conditions (Larocque, 1997; Savva et al., 2010). Given the effective and rapid stomatal control of water loss from transpiration, the formation of photosynthetic products and the storage of carbohydrates are reduced, thereby influencing tracheid development and possibly promoting the lignification and thickening of wood cell walls (McDowell et al., 2008; Hoffmann et al., 2011). Over the past 50 years, the subtropical regions of China have experienced substantial warming. Therefore, the percentage of years with summer droughts has increased. The temperature is quite high during late summer and early fall, and drought stress often occurs (Britez et al., 2014), Nabais et al. (2018) found that in eight out of 10 species, wood density was positively related to drier climatic conditions of provenances. This finding suggests that high species wood density is an adaptive trait associated with drought-prone areas.

When planting foreign provenances at a large scale, the associated gains and risks should be weighed, and the losses resulting from the risks should be economically acceptable. At present, shifting the southern provenances of $P$. massoniana that have shown high wood volume production and have produced particular economic benefits northward by a certain distance seems feasible. This type of provenance shift is often established based on the wood volume production (as determined by individual tree wood volume and survival rate) but ignores wood density as an important indicator of wood quality. In the case of conifers, $95 \%$ of their wood is composed of tracheids (Pritzkow et al., 2014). Tracheids have two key functions: transporting water and nutrients to the tree canopy and providing mechanical support. Earlywood exhibits high transport ability during its formation, and latewood features the highest wood hardness. The proportion of early and latewood and the variation in this xylem characteristic determine the transport capability and mechanical properties of the wood, which play an important role in the ability of trees to cope with unfavourable climatic conditions (Lachenbruch \& McCulloh, 2014). This ability is important because the effects of extreme weather can be long-lasting, and trees may take some time to adapt and be restored to previous growth levels. Patterns of recovery can be considered as indicators of plasticity, and hence the sustainability of tree growth (Eilmann \& Rigling, 2012; Zang, 2012; Taeger et al., 2013; Merlin et al., 2015). This study revealed that when wood density simulations were based on the conditions at seed-source locations, the growth responses to climate change differed among the provenances of $P$. massoniana. Compared with the climates of the experimental sites, the average MXD values for most southern provenances at their places of origin were lower than values at the two planting sites. Because the experimental sites were located in the north-central region of the distribution area, when the northern provenances were transplanted to the south, their MXD values decreased, whereas their 
MND values increased. Increased temperature and precipitation may prolong the growing season of earlywood, resulting in relatively weak resistance and adaptability to drought. When most western and east-central provenances were similarly affected by extreme weather at their origins and at their planting sites, their average MXD values were higher at their places of origin than at the planting sites. This finding indicates that when the western provenances of $P$. massoniana were introduced to the central and eastern regions, their MXD levels did not decrease, and their wood quality and adaptability did not weaken. These findings have theoretical significance for predicting the effects of shifts in planting sites or climate change.

\section{Conclusions}

This study showed that ring density characteristics differed significantly between provenances, and provenance selection could improve the wood density of P. massoniana. MXD and MND exhibited significant genotype-by-environment interaction effects, and significant correlations were found between ring density and temperature and precipitation conditions. These findings suggest that climatic factors and site conditions in addition to genetics can also be strong drivers of wood density variation, and/or that wood density is a highly plastic trait. To offset the impact of future climate change on wood quality, precipitation should be considered as an important climate driver in the region during seed transfer, especially when introducing trees at the Taizi Mountain site.

\section{Acknowledgements}

We thank Zhongcheng $\mathrm{Lu}$ and Tan Chen for help with sample collection at the study sites. This programme was financially supported by the $\mathrm{Na}-$ tional Natural Science Foundation of China (No. 31600533) and the Zhejiang Science and Technology Major Program in New Agricultural Variety Breeding (No. 2016C02056-4).

\section{References}

Battipaglia G, Campelo F, Vieira J, Grabner M, De Micco V, Nabais C, Cherubini P, Carrer M, Bräuning A, Cufar K, Di Filippo A, García-González I, Koprowski M, Klisz M, Kirdyanov AV, Zafirov N \& de Luis (2016) Structure and function of intra-annual density fluctuations: mind the gaps. Frontiers in Plant Science 7: 595. doi:10.3389/ fpls.2016.00595
Bouriaud O, Leban JM, Bert D \& Deleuze C (2005) Intra-annual variations in climate influence growth and wood density of Norway spruce. Tree Physiology 25: 651-660.

Buntgen U, Frank DC, Schmidhalter M, Neuwirth B, Seifert M \& Esper J (2006) Growth / climate response shift in a long subalpine spruce chronology. Trees 20: 99-110. doi:org/10.1007/s00468005-0017-3

Buras A, Sass-Klaassen U, Verbeek I \& Copini P (2020) Provenance selection and site conditions determine growth performance of pedunculate oak. Dendrochronologia 61: 125705. doi:org/10.1016/j.dendro.2020.125705

Braga RC, Paludeto JGZ, Souza BM, Aguiar AV, Pollnow MFM, Carvalho AGM \& Tambarussi EV (2020) Genetic parameters and genotype $\times$ environment interaction in Pinus taeda clonal tests. Forest Ecology and Management 474: 11834.2.

Britez MRD, Sergent AS, Meier AM, Breda N \& Rozenberg P (2014) Wood density proxies of adaptive traits linked with resistance to drought in Douglas fir (Pseudotsuga menziesii (Mirb.) Franco). Trees Structure and Function 28: 1289-1304. doi:10.1007/s00468-014-1003-4

Camarero JJ \& Gutierrez E (2017) Wood density of silver fir reflects drought and cold stress across climatic and biogeographic gradients. Dendrochronologia 45: 101-112.

Cai Q, Liu Y, Liu H, Sun C \& Wang Y (2017) Growing-season precipitation since 1872 in the coastal area of subtropical southeast China reconstructed from tree rings and its relationship with the East Asian summer monsoon system. Ecological Indicators 82: 441-450.

Carrer M \& Urbinati C (2006) Long-term change in the sensitivity of tree-ring growth to climate forcing in Larix decidua. New Phytologist 170: 861872. doi:10.1111/j.1469-8137.2006.01703.x

Chen F, Yuan YJ, Wei WS, Fan ZA, Zhang TW, Shang HM \& Qin L (2012a) Climatic response of ring width and maximum latewood density of Larix sibirica in the Altay Mountains, reveals recent warming trends. Annals of Forest Science 69: 723-733.

Chen F, Yuan YJ, Wei W S, Yu SL, Fan ZA, Zhang RB \& Shang HM (2012b) Temperature reconstruction from tree-ring maximum latewood density of Qinghai spruce in middle Hexi Corridor, China. Theoretical and Applied Climatology 107: 633-643.

Chen F, Yuan YJ, Wei WS, Yu SL \& Zhang TW (2012c) Reconstructed temperature for Yong'an, Fujian, Southeast China: linkages to the Pacific Ocean climate variability. Global and Planetary Change 86-87: 11-19. 
Chen F, Yuan Y, Wei W, Zhang T, Shang H \& Yu S (2015a) Divergent response of tree-ring width and maximum latewood density of Abies faxoniana to warming trends at the timberline of the western Qinling Mountains and northeastern Tibetan Plateau, China. Silva Fennica 49: 1155. doi:10.14214/sf.1155

Chen F, Yuan YJ, Yu SL \& Zhang TW (2015b) Influence of climate warming and resin collection on the growth of Masson pine (Pinus massoniana) in a subtropical forest, southern China. Trees 29: 1423-1430.

Cuny HE, Rathgeber CBK, Frank D, Fonti P, Mäkinen H, Prislan P, Rossi S, del Castillo EM, Campelo P \& Vavrčík H (2015) Woody biomass production lags stem-girth increase by over one month in coniferous forests. Nature Plants 1: 15160. doi:10.1038/nplants.2015.160

Deslauriers A \& Morin H (2005) Intra-annual tracheid production in balsam fir stems and the effect of meteorological variables. Trees Structure and Function 19: 402-408. doi:10.1007/s00468-0040398-8

Eilmann B \& Rigling A (2012) Tree-growth analyses to estimate tree species' drought tolerance. Tree Physiology 32: 178-187.

Fuhrer J, Beniston M, Fischlin A, Frei C, Goyette S, Jasper K \& Pfister C (2006) Climate risks and their impact on agriculture and forests in Switzerland. Climatic Change 79: 79-102.

George JP, Grabner M, Karanitsch-Ackerl S, Mayer K, Weißenbacher L \& Schueler S (2017) Genetic variation, phenotypic stability, and repeatability of drought response in European larch throughout 50 years in a common garden experiment. Tree Physiology 37: 33-46. doi:10.1093/treephys/ tpw085

Grabner M, Wimmer R, Gierlinger N, Evans R \& Downes GM (2005) Heartwood extractives in larch and effects on X-ray densitometry. Canadian Journal of Forest Research 35: 2781-2786. doi:10.1139/x05-196

Hannrup B \& Ekberg I (1998) Age-age correlations for tracheid length and wood density in Pinus sylvestris. Canadian Journal of Forest Research 28: 1373-1379.

Hannrup B, Ekberg I \& Persson A (2000) Genetic correlations among wood, growth capacity and stem traits in Pinus silvestris. Scandinavian Journal of Forest Research 15: 161-170. doi:10.1080/028275800750014966

Hoffmann WA, Marchin RM, Abit P \& Lau OL (2011) Hydraulic failure and tree dieback are associated with high wood density in a temperate forest under extreme drought. Global Change Biology 17: 2731-2742.
Holmes RL (1983) Computer-assisted quality control in tree-ring dating and measurement. TreeRing Bulletin 43: 69-78.

Hylen G (1995) Age-age correlation and relative efficiency of early selection for wood density in young Norway spruce (Picea abies). Icelandic Agricultural Sciences 9: 123-124.

Jiang D, Ding F, Yan X, Hao M \& Dai S (2017) Climate response analysis of Pinus massoniana tree-ring chronologies in Shuangpai County, China. Journal of Resources and Ecology 8: 148-153 (in Chinese). doi:10.5814/j.issn.1674-764X.2017.02.005

Kapeller S, Lexer MJ, Geburek T, Hiebl J \& Schueler S (2012) Intraspecific variation in climate response of Norway spruce in the eastern Alpine range: Selecting appropriate provenances for future climate. Forest Ecology and Management 271: 4657. doi:10.1016/j.foreco.2012.01.039

Klisz M, Buras A, Sass-Klaassen U, Puchałka R, Koprowski M \& Ukalska J (2019) Limitations at the limit? Diminishing of genetic effects in Norway spruce provenance trials. Frontiers in Plant Science 10: 306. doi:10.3389/fpls.2019.00306

Koubaa A, Isabel N, Zhang SY, Beaulieu J \& Bousquet J (2005) Transition from juvenile to mature wood in black spruce (Picea mariana (Mill.) BSP). Wood and Fiber Science 37: 445-455.

Lachenbruch B \& McCulloh KA (2014) Traits, properties, and performance: how woody plants combine hydraulic and mechanical functions in a cell, tissue, or whole plant. New Phytologist 204: 747764. doi:10.1111/nph.13035

Larocque GR (1997) Importance dedifferents parametres climatique sur la croissance et la formation du bois de pin rouge (Pinus resinosa Ait) en Ontario (Canada). Annals of Forest Science 54: 51-63.

Laura P, Nardini A, von Arx G, Saurer M and Cherubini P (2017) Isotope signals and anatomical features in tree rings suggest a role for hydraulic strategies in diffuse drought-induced die-back of Pinus nigra. Tree Phytologist 37: 523-535.

Li YJ, Dong ZP, Chen DL, Zhao SY, Zhou FF, Cao XG \& Fang KY (2019) Growth decline of Pinus Massoniana in response to warming induced drought and increasing intrinsic water use efficiency in humid subtropical China. Dendrochronologia 57: 125609. doi: 10.1016/j.dendro.2019.125609

Lindner M, Maroschek M, Netherer S, Kremer A, Barbati A, Garcia-Gonzalo J, Seidl R, Delzon S, Corona P \& Kolstrom M (2010) Climate change impacts, adaptive capacity, and vulnerability of European forest ecosystems. Forest Ecology and Management 259: 698-709. doi:10.1016/j.foreco.2009.09.023

Ling JJ, Xiao Y, Hu JW, Wang FD, Ouyang FQ, Wang H, Weng YH \& Zhang HG (2021) Genotype by en- 
vironment interaction analysis of growth of Picea koraiensis families at different sites using BLUPGGE. New Forests 52: 113-127. doi:10.1007/ s11056-020-09785-3

Liu QH, Jin GQ, Zhang R, Chu DY, Qin GF \& Zhou ZC (2009) Provenance variation in growth, stemform and wood density of Masson Pine at 24 year old and the provenance division. Scientia Silvae Sinicae 45: 55-61.

Liu Q, Zhang R, Jin G, Chu D \& Zhou ZC (2010) Variation of ring width and wood basic density and early selection of Pinus massoniana provenances. Scientia Silvae Sinicae 46: 49-54.

Matisons R, Jansone D, Elferts D, Adamovics A, Schnecc V \& Jansons A (2019) Plasticity of response of tree-ring width of Scots pine provenances to weather extremes in Latvia. Dendrochronologia 54: 1-10. doi:10.1016/j.dendro.2019.01.002

McDowell N, Pockman WT, Allen CD, Breshears DD, Cobb N, Kolb T, Plaut J, Sperry J, West A, Williams DG \& Yepez EA (2008) Mechanisms of plant survival and mortality during drought: why do some plants survive while others succumb to drought? New Physiology 178: 719-739. doi:10.1111/j.1469-8137.2008. 02436.x

Merlin M, Perot T, Perret S, Korboulewsky N \& Vallet P (2015) Effects of stand composition and tree size on resistance and resilience to drought in sessile oak and Scots pine. Forest Ecology and Management 339: 22-33. doi:10.1016/j.foreco.2014.11.032

Nabais C, Hansen JK, David-Schwartz R, Klisz M, López R \& Rozenberg P (2018) The effect of climate on wood density: What provenance trials tell us? Forest Ecology and Management 408: 148-156. doi:10.1016/j.foreco.2017.10.040

Nicotra AB, Atkin OK, Bonser SP, Davidson AM, Finnegan EJ, Mathesius U, Poot P, Purugganan MD, Richards CL, Valladares F \& van Kleunen M (2010) Plant phenotypic plasticity in a changing climate. Trends Plant Science 15: 684-692. doi:10.1016/j.tplants.2010.09.008

Pritzkow C, Heinrich I, Grudd H \& Helle G (2014) Relationship between wood anatomy, tree-ring widths and wood density of Pinus sylvestris L. and climate at high latitudes in northern Sweden. Dendrochronologia 32: 295-302. doi:10.1016/j. dendro.2014.07.003

Sakamoto Y, Ishiguro M \& Kitagawa G (1986) Akaike information criterion statistics. Reidel, Dordrecht.

Sattler DF, Finlay C and Stewart JD (2015) Annual ring density for lodgepole pine as derived from models for earlywood density, latewood density and latewood proportion. Forestry 88: 622-632. doi:10.1093/forestry/cpv030
Savva Y, Koubaa A, Tremblay F \& Bergeron Y (2010) Effects of radial growth, tree age, climate, and seed origin on wood density of diverse jack pine populations. Trees Structure and Function 24: 53-65. doi:10.1007/s00468-009-0378-0

Schlyter P, Stjernquist I, Barring L, Jonsson AM \& Nilsson C (2006) Assessment of the impacts of climate change and weather extremes on boreal forests in northern Europe, focusing on Norway spruce. Climate Research 31: 75-84.

Schwarz G (1978) Estimating the dimension of a model. Annals of Statistics 6: 461-464.

Searle SR, Casella G \& McCulloch CE (1992) Variance components. Wiley, New York, USA.

Seo JW, Eckstein D, Jalkanen R \& Schmitt U (2011) Climatic control of intra- and inter-annual wood-formation dynamics of Scots pine in northern Finland. Environmental and Experimen Botany 72: 422-431. doi:10.1016/j.envexpbot.2011.01.003

Taeger S, Sparks TH \& Menzel A (2015) Effects of temperature and drought manipulations on seedlings of Scots pine provenances. Plant Biology 17: 361-372. doi:10.1111/plb.12245

Taeger S, Zan, C, Liesebach M, Schneck V \& Menzel A (2013) Impact of climate and drought events on the growth of Scots pine (Pinus sylvestris L.) provenances. Forest Ecology and Management 307: 30-42. doi:10.1016/j.foreco.2013.06.053

Takaaki F, Kazuhito K, Kazuko U, Makoto K, Hisashi A \& Kazuyuki O (2006) Age trends in the genetic parameters of wood density and the relationship with growth rates in hybrid larch (Larix gmelinii var. Japonica $\times$ L. kaempferi) $\mathrm{F}_{1}$. Journal of Forest Research 11: 157-163. doi:10.1007/s10310-0050200-9

Valladares F, Sanchez-Gomez D \& Zavala MA (2006) Quantitative estimation of phenotypic plasticity: Bridging the gap between the evolutionary concept and its ecological applications. Journal of Ecology 94: 1103-1116. doi:10.1111/j.13652745.2006.01176.x

Venegas-González A, von Arx G, Chagas MP \& Filho MT (2015) Plasticity in xylem anatomical traits of two tropical species in response to intra-seasonal climate variability. Trees Structure and Function 29: 423-435.

Vitasse Y, Francois C, Delpierre N, Dufrene E, Kremer A, Chuine I \& Delzon S (2011) Assessing the effects of climate change on the phenology of European temperate trees. Agricultural and Forest Meteorology 151: 969-980. doi:10.1016/j.agrformet.2011.03.003

Wang L, Duan J, Chen J, Huang L \& Shao X (2010) Temperature reconstruction from tree-ring maximum density of Balfour spruce in eastern Tibet, China. International Journal of Climatology: A 
Journal of the Royal Meteorological Society 30: 972-979.

Wang T, Hamann A, Yanchuka A, O'Neill GA \& Aitken SN (2006) Use of response functions in selecting lodgepole pine populations for future climates. Global Change Biology 12: 2404-2416. doi:10.1111/j.1365-2486.2006.01271.x

Xiang WH, Liu SH, Deng XW, Shen AH, Lei XD, Tian DL, Zhao MF \& Peng CH (2011) General allometric equations and biomass allocation of Pinus massoniana trees on a regional scale in southern China. Ecological Research 26: 697-711.

Zang C, Pretzsch H \& Rothe A (2012) Size-dependent responses to summer drought in Scots pine,
Norway spruce and common oak. Trees Structure and Function 26: 557-569. doi:10.1007/s0046801-1-0617-z

Zobel BJ \& van Buijtenen JP (1989) Wood variation: its causes and control. Springer-Verlag, Berlin Germany.

Zubizarreta-Gerendiain A, Gort-Oromi J, Mehtatalo L, Peltola H, Venalainen A \& Pulkkinen P (2012) Effects of cambial age, clone and climatic factors on ring width and ring density in Norway spruce (Picea abies) in southeastern Finland. Forest Ecology and Management 263: 9-16. doi:10.1016/j. foreco.2011.09.011 